6-18-2003

\title{
Impeachment of Witnesses: A Walking Tour
}

Lynn McLain

University of Baltimore, lmclain@ubalt.edu

Follow this and additional works at: http://scholarworks.law.ubalt.edu/all_fac

Part of the Evidence Commons

\section{Recommended Citation}

Lynn McLain, Impeachment of Witnesses: A Walking Tour, (2003).

Available at: http://scholarworks.law.ubalt.edu/all_fac/925

This Conference Proceeding is brought to you for free and open access by the Faculty Scholarship at ScholarWorks@University of Baltimore School of Law. It has been accepted for inclusion in All Faculty Scholarship by an authorized administrator of ScholarWorks@University of Baltimore School of Law. For more information, please contact snolan@ubalt.edu. 


\title{
IMPEACHMENT OF WITNESSES: A WALKING TOUR
}

\author{
MARYLAND STATE'S ATTORNEYS' CONVENTION \\ OCEAN CITY, MD \\ JUNE 18, 2003
}

\author{
Professor Lynn McLain \\ University of Baltimore School of Law
}

\section{Methods of Impeachment in General}

The methods of impeachment are summarized in Rule 5-616. There are two general approaches to impeaching a witness.

\section{A. "Liar, Liar, Pants on Fire"}

One is to show that the witness is a liar, and that therefore the jury should not credit his or her testimony. The methods employed most frequently in this endeavor include:

1. The witness's prior convictions (per Rule 5-609; Rule 5-616(a)(6));

2. The witness's pertinent prior bad acts, which have not resulted in his or her criminal conviction (per Rule 5-608(b); Rule 5-616(a)(6));

3. The witness's bad reputation for truthfulness, or another witness's bad opinion of the first witness's truthfulness (per Rule 5-608(a); Rule 5$616(h)(6))$;

4. The witness's bias, interest, prejudice, or improper motive, giving him or her a reason to lie (Rule 5-616(a)(4)); and

5. The witness's prior inconsistent statements (inability to "keep his or her story straight") (Rules 5-613, 5-616(a)(1)).

See also Rule 5-616(a)(3) (that witness does not hold an opinion testified to by the witness) and Rule 5-616(a)(5) (witness lacks first-hand knowledge).

\section{B. Anybody Can Make a Mistake}

The second approach to impeachment, also much employed, but far less dramatic and confrontational, is to show that the witness, even if well-meaning, is mistaken. The methods used here include attacks on the witness's perception and memory, such as by: 
1. Bad eyesight, hearing, etc. (Rule 5-616(a)(5));

2. Use of drugs or alcohol at pertinent time (either time of event or when testifying) (Rule 5-616(a)); ;

3. Conditions under which witness's observation were made, e.g., poor lighting, witness upset, fearful (Rule 5-616(a)(5));

4. Bias that may have affected perception and memory (Rule 5-616(a) ); ;

5. Suggestiveness of, e.g., identification procedure (Rule 5-616);

6. Prior inconsistent statements, closer to the time of the event, when memory was fresher (Rules 5-613; 5-616(a)(1)); and

7. Contradictory substantive evidence from other witnesses who observed same event (this has the secondary effect of also impeaching this witness's recollection) (Rule 5-616(a)(2)-(3)).

\section{Whom Can One Impeach?}

Rule 5-607 provides that one can impeach any witness, including one's own. At times, one may truly wish to discredit the witness one has called.

Often, however, one impeaches one's own witness on direct, not because one wishes to discredit the witness, but to "draw the sting" from the cross-examiner's being the one to impeach the witness. Clemmons v. State, 352 Md. 49 (1998) (State may bring out on direct that accomplice/State's witness has pled guilty to a crime arising from same criminal conduct as that charged).

\section{A. The Old Common Law Rule}

Under the common law "voucher rule" (now generally overruled by Rule 5-607, with one exception), counsel, as an officer of the court, vouched for the credibility of his or her witnesses. Under the voucher rule, one could impeach one's own witnesses in only three limited circumstances.

First, one could impeach the witness one had called, if the witness was the opposing party or had a direct interest in the outcome of the suit. (Under Title 5, impeachment remains available under this circumstance of an opposing party or one "identified with an adverse party." $C f$. Rule $5-611(\mathrm{c})(2)$. 
Second, one could impeach a witness whom one was required by law to call, e.g., an attesting witness to a will. (This result should also obtain under the Rules.)

Third, at common law, one could impeach a "turncoat" witness, only if two criteria were met: (1) one was surprised by the witness's testimony at trial and (2) it affirmatively damaged one's case (not just disappointed one, because of a lack of expected evidence). Then one could impeach the witness, but by only his or her prior inconsistent statements (not prior convictions, etc., because, after all, counsel had vouched for the witness's credibility). If counsel knew beforehand that the witness was a "turncoat" or that the witness was unreliable, but the witness was needed to testify, counsel would ask the court to call the witness as a court's witness. Then both counsel could cross-examine.

\section{B. The Current Rule}

Although Rule 5-607 provides that counsel may impeach any witness (and Rule 5-806 any hearsay declarant whose out-of-court statement is admissible as substantive evidence), the case law construing the Rules precludes counsel from calling a witness simply to prove the witness's prior inconsistent statement, when the statement is not admissible as substantive evidence. Spence v. State, 321 Md. 526 (1991). Thus, in effect, the common law requirement of surprise is retained: if one knows before trial that the witness has changed her story, and the prior statement does not fall under a hearsay exception, see Stewart v. State, 104 Md. App. 273 (1996), one cannot call the witness to prove the statement.

Even if one expects favorable testimony on one subject from a witness, one may not call the witness and then inquire into an "independent line of inquiry," as to which one does not expect favorable substantive evidence, so as to introduce a prior inconsistent statement. Bradley v. State, 333 Md. 593 (1994).

In Walker v. State, 373 Md. 360, 388 (2003), the Court of Appeals further explicated the Spence rule as follows:

If the witness's testimony is relevant to matters other than the "recanting" statements, then the witness was not called as a subterfuge and the question eliciting the "recanting" statements must be scrutinized to determine whether the question concerned an "independent area of inquiry." When the area of inquiry is clearly not independent, then "the State may impeach those portions of a witness's testimony that do not comport with the prosecution's theory of the case."

(Emphasis added.)

When the question pertains to a subject for which the witness has given some helpful testimony, and failure to address this particular point would " paint an incomplete picture" and 
thus could well "lead the jury to draw inferences adverse to the State's case," the impeachment does not violate Spence. $373 \mathrm{Md}$. at $388 \mathrm{n} .9,390$. This was held to be the case in Walker.

Even if the area of inquiry is independent, however, the State may perhaps impeach the witness -- but then only if the State did not have "full knowledge" of the impending change in the witness's testimony. This criterion of lack of full knowledge was also held to have been met in Walker. $373 \mathrm{Md}$. at 389-90.

\section{Impeachment by Attacks on Witnesses' Character for Truthfulness}

Any witness who testifies, including any party who testifies (or, indeed, any hearsay declarant whose OCS (out-of-court statement) is admitted for TOMA (the truth of the matter asserted by the out-of-court declarant), see Rule 5-806) puts his or her character for truthfulness and veracity at issue in the case. Rules 5-609 (prior convictions) and 5-608 (prior bad acts and character witness testimony) flow from this result.

\section{A. Prior Convictions}

\section{Eligible Crimes}

The universe of impeachment-eligible convictions under Rule 5-609 embraces "infamous crimes" and other crimes relevant to credibility, as to which the conviction occurred less than 15 years before the witness begins testifying.

It does not include PBJ's; juvenile delinquency adjudications; convictions that have been reversed or pardoned; convictions for crimes as to which the defendant was denied the right to counsel; or convictions as to which an appeal -- or the time in which to file an appeal -- is pending.

Hence the usual manner of proof: ("Are you the same X who was convicted of $\mathrm{Y}$ crime in Baltimore City, Maryland, on $\mathrm{Z}$ date, when you were over 18 years of age and represented by counsel?"). You cannot go into the details of the crime, though the courts allow you to prove the sentence received. State v. Giddens, $335 \mathrm{Md}$. 205, 222 (1994).

If the witness denies the conviction, you then may offer a certified copy of the public record of the conviction into evidence. You are required to have this record before you can ask the question. See Taylor v. State, $278 \mathrm{Md}$. 150, 154 (1976) ("preferable practice" is "a proffer by the prosecutor, out of the presence of the jury, of the evidence which it proposes to offer to prove"). 


\section{Balancing Test}

All these crimes are subject to a balancing test. The judge may permit impeachment, only if the prior conviction's probative value as to the witness's (or hearsay declarant's character for truthfulness under oath outweighs the risk of any unfair prejudice that may result from its admission. See generally Jackson v. State, $340 \mathrm{Md}$. 705 (1995) (relevant factors include "(1) the impeachment value of the prior crime; (2) the point in time of the conviction and the defendant's subsequent history; (3) the similarity between the past crime and the charged crime; (4) the importance of the defendant's testimony; and (5) the centrality of the defendant's credibility").

See Brown v. State, 373 Md. 234, 246-51 (2003) (Harrell, J., concurring) (no abuse of discretion in admitting, in trial for second degree assault, defendant's prior conviction for possession of CDS with intent to distribute); Facon v. State, 144 Md. App. 1, 45-48, 796 A.2d 101 (2002), cert. granted, 369 Md. 570, 801 A.2d 1031 (2002) (even if issue had been preserved for appeal, no abuse of discretion in permitting armed robbery defendant to be impeached with two of his six prior convictions for armed robbery, when defendant's credibility was highly important to case); Calloway v. State, 141 Md. App. 114, 121-23 (2001), cert. denied, 367 Md. 722 (2002) (12-year-old conviction for auto theft was properly admitted to impeach defendant, who was charged with second degree assault, robbery, and felony theft; probative value of prior conviction outweighed any unfairly prejudicial effect).

\section{First, the Good News: Waiver by Defendant}

A defendant who introduces her own prior conviction, on direct, to "draw the sting," waives the right to complain on appeal of the trial judge's ruling that he would permit the State to impeach her with that conviction. Brown v. State, 373 Md. 234 (2003).

\section{Problems}

Evaluate the admissibility, under Maryland law, of the following convictions, when offered against a criminal defendant, charged with attempted murder. The defendant has testified that he acted in self-defense.

1. Shoplifting (W convicted 8/06/01).

2. Burglary (W convicted 1/13/88).

3. 13-year-old conviction for mail fraud.

4. 5-year-old conviction for petty larceny (maximum sentence is 6 months) (see Prout v. State, 311 Md. 348, 364 (1988)). 
5. 8-year-old conviction for possession of cocaine with intent to distribute, served 6 years (see State v. Giddens, 335 Md. 205 (1994)).

6. 1-year-old conviction for making a false statement (on shipping report, so as to get by a trade embargo).

7. 9-year-old conviction for child molestation (see Hopkins v. State, 137 Md. App. $200(2001))$.

8. 9-year-old conviction for assault on a police officer (compare Linkins v. State, $202 \mathrm{Md} .212$ (1953) (no abuse of discretion to permit defendant charged with, inter alia, assault, to be impeached with a prior conviction of assault on a police officer) with Fulp v. State, $130 \mathrm{Md}$. App. 157 (2000) ("the impeachment value of the crime of assault with intent to murder is zero"; defendant was charged with murder).

9. First degree murder (W convicted $8 / 5 / 83$ ).

\section{Now, the Bad News: "Sanitized" References}

\section{a. "Heads, You Lose" (if the State wants it, no)}

The Court of Special Appeals followed the minority rule among American jurisdictions when it found reversible error in a trial court's having permitted the State to make "sanitized" references to the fact that the defendant had previously been convicted of "felonies," without naming the felonies. Bells v. State, 134 Md. App. 299 (2000). Contra, e.g., U.S. v. Hursh, 217 F.3d 761 (9th Cir. 2000).

\section{b. “Tails, I Win" (if the defense wants it, yes)}

In Carter v. State, 2003 WL 21077425 (Md. May 14, 2003), the Court of Appeals held that, when the defense offers to stipulate to the status part of a charged crime, such as possession of a gun by a person who has been convicted of a crime of violence, the court must accept the stipulation, and must instruct the jury only that the defendant "has been convicted of a crime for which he or she is prohibited from possession a regulated firearm under the law."

The Court of Appeals acknowledged that, in so holding, its protection of the defendant charged with such a status crime exceeds that established for the federal courts in Old Chief $v$. United States, 519 U.S. 172 (1997), which permits the trial court to address this question in its discretion under Fed. R. Evid. 403.

The Court of Appeals' decision imposes a uniform result for all Maryland courts, regardless of the particular type of qualifying crime underlying the prior conviction. 


\section{Judge's Instruction to Defendant}

The trial court is not required to inform an accused of the possibility of his or her impeachment, should he or she testify - but if the judge undertakes to give such a warning, the judge must do so correctly. Morales v. State, 325 Md. 330, 335 (1992); Sutton v. State, 139 Md. App. 412, 441 (2001), cert. denied, 366 Md. 249, 783 A.2d 223 (2001).

\section{B. Prior Bad Acts that Did Not Result in a Conviction}

Rule 5-608(b) permits the court, in its discretion, to allow inquiry into what the witness has done, but not been convicted for, that the judge finds probative of the witness's character for untruthfulness. (Rules 5-403 and 5-611(a) may also come into play.) (Counsel must have a reasonable factual basis for the inquiry! See Rule 5-608(b).)

1. If the witness denies them, counsel may not prove these bad acts by extrinsic evidence (evidence other than through the witness's own testimony).

E.g., W under-reports his income on his tax returns. (If $\mathrm{W}$ denies this, can counsel show him the tax return to refresh his memory? If he still denies it, can counsel call his boss to prove it?)

2. Note, as always, what may be inadmissible without more may become admissible if a party makes sweeping claims, such as "I've never told a lie in my life!"

3. Problems.

a. W was convicted of a crime, but the conviction is inadmissible under Rule 5-609, because of remoteness in time. May counsel ask W about the underlying act, under Rule 608(b)? (No.)

b. W was acquitted of a crime. May counsel ask W about the alleged underling act, under Rule 5-608(b)? (Perhaps. Does counsel have a "reasonable factual basis" for the question?) 


\section{Impeachment by Character Witness Testifying as to One's Character for Untruthfulness}

\section{Proof May Be by Either Reputation Testimony or Opinion Testimony}

Once a witness has testified (or a hearsay declarant's out-of-court statement has ben admitted as substantive evidence), Rule 5-608(a) permits counsel to call character witnesses to testify as to either:

a. The principal witness's bad reputation, in the community which they share, for truthfulness; or

b. The character witness's bad opinion, based on the character witness's sufficient first-hand knowledge, of the principal witness's character for truthfulness.

\section{Reputation Testimony}

Elicitation of reputation testimony from a "community mouth" witness is short and sweet:

Q: Do you know X? (or, Have you heard of X?)

A: Yes, we go to the same school [or live in the same neighborhood, etc. (or "Not personally, but we go to the same school," etc.].

Q: Does $\mathrm{X}$ have a reputation in that [community] regarding his truthfulness?

A: $\quad$ Yes.

Q: What is that reputation?

A: It is bad.

\section{Opinion Testimony}

\section{a. In General}

Elicitation of opinion testimony was intended to be similarly short and sweet: Does the character witness $(W)$ know the principal witness $(X)$ ? How does she know $X$ (work together, go to the same school, church, etc.)? Over the period of time $W$ has known $X$, has $W$ formed an opinion as to X's character for truthfulness? What is that opinion? Answer: " $\mathrm{X}$ is a liar." The character witness may not testify as to whether he or she believes the principal witness's testimony in the case to be truthful. Rule 5$608(\mathrm{a})(3)(\mathrm{A})$.

The drafters of the Rules contemplated that the basis for such opinion testimony on direct would be where and how long $\mathrm{W}$ has known $\mathrm{X}$, e.g., "We've worked together in a small office 
for 10 years." Compare, e.g., Durkin v. State, 284 Md. 445, 453, 397 A.2d 600 (1979) (police officer who had brief encounter with witness when witness had made larceny report, which officer concluded was false, lacked sufficient basis for his opinion as to witness's truthfulness to be admissible) with Barnes v. State, 57 Md. App. 50, 57-60, 468 A.2d 1040 (1984) (character witness had adequate basis for opinion when she had known individual well for last two years, had been acquainted with her for several years before that, and had interviewed her several times to verify addresses and confirm leads).

Specific acts that led to W's opinion, e.g., " $\mathrm{X}$ regularly steals from the vending machine," cannot be brought out on direct. (Why not? Time; distraction of jury from main issues in case; need would result to cross and possibly bring in extrinsic evidence, as to whether the specific acts occurred)

\section{b. Jensen Changed the Rule}

In Jensen v. State, 355 Md. 692 (1999), however, the Court of Appeals made Rule 5-608 (a) more difficult to apply. It held that the trial judge had abused his discretion in precluding a defense character witness from testifying on direct - before the jury and not just before him, for Rule 5-104(a) purposes - that the principal witness had "often told her mutually inconsistent stories."

The Court of Appeals held that, although specific instances are not permitted on direct, "something more" than just where and how long the character witness had known the principal witness is permissible on direct. Just where the line falls between the now required "something more" and forbidden "specific instances" is a tough call. See O'Day, A Comparison of the Use of Character Witness Testimony in Maryland Versus the Federal Practice: Distinguishing Reasonable Basis from Specific Instances of Conduct after Jensen v. State, 355 Md. 692, 736 A.2d 307 (1999), 30 U. BALT. L. REV. 127 (2000).

\section{Cross-Examination of Character Witness}

On cross-examination, Rule 5-608(a) permits a character witness to be asked about specific instances of the principal witness's conduct inconsistent with the accuracy of the unfavorable reputation or opinion to which the witness has testified. For example, the crossexaminer might ask, "Did you know [or, "Have you heard ..."] that in X's night school law class the professor made an arithmetical error in X's favor, and X voluntarily came forward to tell the professor, so that the professor could lower X's grade?"

This inquiry is permitted only for the limited purpose of impeaching the character witness's testimony, and not as substantive evidence that the principal witness committed the conduct. A limiting instruction under Rule 5-105 should be given on request. 
Upon objection, questioning counsel must provide a "reasonable factual basis" for the question. Rule 5-608(a)(4)(A). The questioner may not provide extrinsic evidence of this specific instance if the witness denies knowledge.

The State may not ask a "guilt-assuming" hypothetical, regarding the current charge. See United States v. Mason, 993 F.2d 406 (4th Cir. 1993).

\section{Impeachment by Bias, Interest, or Improper Motive}

\section{A. In General}

Impeachment by bias, interest, improper motive, or "fear or favor," is always permissible. See United States v. Abel, 469 U.S. 45 (1984); Md. Rule 5-616(a)(4).

For example, the Court of Appeals found reversible error when the trial court had refused to permit a criminal accused's attorney to cross-examine the complaining witness as to whether he had hired an attorney to file a civil suit related to the criminal charges. Martin v. State, 364 Md. 692 (2001). See also Smith v. State, 371 Md. 496, 501-06 (2002) (no abuse of discretion in permitting certain exploration of bias or interest, but precluding inquiry into unclear, "smoke-filled tangents"); Wilson v. State, 363 Md. 333 (2001) (State's failure to disclose that two State's witnesses-accomplices were testifying pursuant to plea agreements was reversible Brady violation).

The State may bring out on direct the fact that an accomplice who has become a State's witness has pled guilty to a crime arising from the same criminal conduct as that charged, for the "purpose of exposing in advance the basis for a credibility attack on the damaging testimony that the witness gave." Clemmons v. State, 352 Md. 49, 58 (1998).

\section{B. Confrontation Clause}

The confrontation clause may even require permitting an accused to bring out otherwise protected information, such as a juvenile witness's probationary status, if relevant to bias. See Davis v. Alaska, 415 U.S. 308 (1974). See Ebb v. State, 341 Md. 578 (1996) (trial judge has no discretion to preclude cross-examination as to a state's witness's probationary status pending charges, or pending sentencing, only if there is reason to believe that the witness is trying to shift blame from himself or herself to the defendant for the charged crime; in other situations, trial judge should hold a hearing outside jury's presence and engage in a balancing process).

An accused's confrontation right will mandate the admission of an impeaching fact that provides a direct motive for a prosecution witness to falsely accuse the defendant. See Quinn $\boldsymbol{v}$. Haynes, 234 F.3d 837 (4th Cir. 2000), cert. denied, 532 U.S.1024 (2001) (no violation of either Davis v. Alaska principle or confrontation right for state court to preclude cross-examination of child abuse victim about her unrelated similar complaints against others; fact that those accused 
also denied guilt was merely an attack on child's general credibility, rather than her potential bias or motive to fabricate changes against defendant); Boggs v. Collins, 226 F.3d 728 (6th Cir. 2000), cert. denied, 532 U.S. 913 (2001) (no deprivation of confrontation right to preclude crossexamination of rape victim about her alleged false accusation of unrelated rape by another person, as it constituted an attack on her general credibility rather than a fact creating a motive to falsely accuse defendant).

\section{Extrinsic Evidence}

Bias, etc., are believed to be such important impeaching facts that they may be proved by extrinsic evidence. This is most appropriate if the witness declines to admit the impeaching fact (though Maryland law does not require this as a prerequisite to extrinsic evidence). Rule 5$616(\mathrm{~b})(3)$.

\section{Matters of Religion}

By virtue of Rule 5-610, counsel can no longer impeach a witness on the ground that the witness lacks religion (nor bolster it by showing the witness's religion). Religion may incidentally emerge, however, because relevant to bias or because character witness knows $\mathrm{D}$ because she sings with $\mathrm{D}$ in the church choir, etc.).

\section{Mental and Sensory Defects or Weaknesses}

\section{A. In General}

Witnesses may be impeached by questioning of them about facts probative of their inability to perceive, remember, or communicate, or their weaknesses in those abilities, such as their having been under the influence of drugs or alcohol at one time of the event to which the witness is testifying (or while testifying), Lyba v. State, 321 Md. 564 (1991), or head injuries causing memory loss. Clark v. State, 364 Md. 611, 774 A.2d 1136 (2001) (reversible error to preclude defense from questioning State's key witness about his workers compensation claim eight years before trial and three years after charged crimes, in which he alleged he suffered from bouts of memory loss).

Rule 5-403 may come into play. See Clark v. State, 140 Md. App. 540, 604-05, 781 A.2d 913 (2001), cert. denied (Md. Apr. 12, 2002) (no abuse of discretion to permit defendant to cross-examine child victim's father as to whether he was using alcohol heavily over 4-month period preceding child's abduction, but not to permit inquiry as to his marijuana use).

\section{B. Psychiatric History}

Witnesses' history of psychiatric treatment may be protected by the court, under Rules 5611(a) and 5-403, unless particularly probative. See Thomas v. State, 372 Md. 342, 346-47, 349- 
50, 358-59 (2002) (no abuse of discretion, after in camera review of pertinent Maryland state hospital records, to preclude defense both from discovery of those and of non-state hospital records, and also from questioning witness regarding her psychiatric history, other than her selfdescribed "weird feelings").

\section{Extrinsic Evidence}

Extrinsic evidence may be admitted to prove that, for example, a witness was on medication at the time of the event, if the witness, if possible, has been examined about it and "has failed to admit it." Rule 5-616(b)(4).

Extrinsic evidence will also be admissible to prove that a witness lacked first-hand knowledge of that to which the witness has testified. E.g.,

Allison Klein, The Baltimore Sun, 4/24/02, 3B.

\section{Witness seems to contradict testimony}

Man's view of shooting was not as clear as he claims, woman says

A woman testifying yesterday in the trial of a man accused of shooting a Baltimore police officer and a teen-ager last year appeared to contradict the statements of an earlier witness who said he saw Donnell A. Ward shoot the two.

On Monday, Martin Spriggs testified that he saw the shootings of police Officer Willie D. Grandy and the teen-ager from a window of a house in the 700 block of Wharton Court, a few feet from the incident.

But Brenda Johnson, who lives in the same house testified that the window that faced the shooting scene was closed that afternoon, and that it "would not be true" if Spriggs testified that the window was open and allowed him a clear view of the shooting.

\section{A Witness's Prior Inconsistent Statements}

\section{A. Counsel's Choice as to Statements that Fit Within Rule 5-802.1(a)}

Counsel may offer those inconsistent statements that do not fall under any hearsay exception only to impeach.

Under the rule of Nance v. State, 331 Md. 549 (1993), codified in Rule 5-802.1(a), counsel may offer certain prior inconsistent statements of a witness as substantive evidence. Counsel may also choose instead to offer these only for the limited purpose of impeachment. But 
cf. Wright v. State, 349 Md. 299 (1998) (State can't hold back defendant's admission, admissible under Rule 5-803(a)(1), to use in rebuttal for impeachment).

\section{B. Queen Caroline Rules No Longer}

Under the common law "Queen Caroline's Rule," before counsel wishing to impeach a witness, could ask a witness about the witness's prior statement, counsel had to relate to the witness the time, place, and substance of the statement and to whom it was made. If the prior statement was in writing, counsel had to show it to the witness, before asking the witness about it. Counsel couldn't just ask the witness, e.g., "You testified today the light was green for D. Did you ever say the light was red for D?"

Md. Rule 5-613 overrruled the common law Queen Caroline's rule. Now counsel may ask the witness about the prior statement without laying a foundation, but before passing the witness to opposing counsel, must then provide the information that would have been required under Queen Caroline's rule, and give the witness an opportunity to deny or explain the prior statement.

\section{When is Extrinsic Evidence Permitted?}

"Unless the interests of justice otherwise require" (Rule 5-613(b)), only if counsel has disclosed the details of the prior statement to the witness, and the witness has "failed to admit having made the statement," may counsel use extrinsic evidence to prove the prior statement. See McCracken v. State, 150 Md. App. 330 (2003) (reversible error to permit extrinsic evidence in rebuttal, when State had failed to give declarant-defendant an opportunity to explain on cross); Hardison v. State, $118 \mathrm{Md}$. App. 225 (1997). (This is where the Georgia prosecutor fell down in the trial of Baltimore Ravens' Ray Lewis and his co-defendants, Sweeting and Oakley, as to limo driver, Duane Fassett.)

Even then, extrinsic proof may be used only if the prior statement relates to a material, non-collateral matter. The subject matter of a prior inconsistent statement is non-collateral if that subject matter would have been a proper subject of proof, even if the witness had not testified. 
Problems. Which of the following statements concerns collateral matters, and which noncollateral? The case is a red-light green-light case, and W has testified that he is an unemployed law student, the light was red for $\mathrm{P}$, and that $\mathrm{W}$ has never accepted a bribe to give false testimony. W said earlier, pretrial, to P's investigator, that:

1. The light was green for $P$.

2. W is CEO of General Motors.

3. W accepted a bribe to give false testimony in another case.

(Only \#1 is non-collateral.)

\title{
D. The "Interests of Justice" Exception
}

In Fontaine v. State, 134 Md. App. 275, 297 (2000), the Court of Special Appeals, in an opinion by Judge Kenney, set forth its recommended analysis with regard to whether extrinsic evidence of a prior inconsistent statement should be admitted under the "interests of justice" exception:

\begin{abstract}
Faced with a request to admit a prior inconsistent statement under the "interests of justice" exception to Maryland Rule 5-613, we believe it is appropriate and useful to consider the request against the backdrop of the factors suggested by Weinstein: (1) the practicability of recalling the witness, including that witness's availability; (2) the significance of the issue to which the statement relates; (3) the probative value of the statement for impeachment purposes; (4) balancing the consequences of not allowing the statement into evidence with the likelihood that, if questioned, the witness could deny the statement or provide a reasonable explanation; and (5) the efficacy of an instruction to a jury that has heard a prior inconsistent statement without comment by the witness who made the statement. To that calculus we would include consideration of the good faith and reasonable diligence of counsel in discovering the prior inconsistent statement sought to be introduced. These factors provide a conceptual matrix within which the totality of all the applicable circumstances can be considered in arriving at an "interests of justice" determination. We do not hold, however, that the trial court must individually evaluate and expressly comment on each factor.
\end{abstract}

In Fontaine, the CSA held that it was not an abuse of discretion to preclude the evidence offered by the defense, when the defense counsel had concurred in the excusing of a State's witness, but then the next day proffered extrinsic evidence of the witness's noncollateral inconsistent statement, and the witness lived out of state and could not be located.

\section{E. Discovery under Rule 4-263}

Be extra careful as to discovery under Rule 4-263(a)(2)(C), when the witness will testify to an out-of-court identification of the defendant, but had made prior statements inconsistent with the i.d., such as "I didn't see anything." See Collins v. State, 373 Md. 99 (2003) (nondisclosure resulted in reversible error). 


\section{The Monkey Wrench of Walker v. State}

In Walker v. State, $373 \mathrm{Md} .360$ (2003), the Court of Appeals held that the assistant state's attorney, in asking leading questions on direct of a partially "turncoat" State's witness (at trial, he admitted his own guilt in selling drugs but tried to keep Walker, his alleged supplier, out of it) to impeach him with statements he had made to her in her office (in this case, when his own attorney also was present), deprived the defendant of his right to a fair trial. The testimony and colloquies at the bench are set forth in Appendix A of this packet (pp. 22-25). The prosecutor asked, for example, whether she had previously given the witness, Myrick, a copy of his statement to the police (implicating Earl Walker) and had asked him whether it was true.

Based on the ASA's leading questions, the Court of Appeals in Walker painted the ASA as an unsworn witness, saying: "When the prosecutor testifies in the guise of questioning a witness, the defendant's confrontation rights are implicated." $373 \mathrm{Md}$. at 397. The Court of Appeals concluded:

The prosecutor intimated, by her questions, that Myrick was lying on the stand and that in fact he had made inconsistent statements to the prosecutor before the trial. The prosecutor also stated multiple times that she knew Myrick's mental state and that he was afraid of telling the truth on the stand. The effect of her repetitious assertions that she knew Myrick was changing his story on the stand out of fear of retaliation encouraged the jury to accept the content of her questions as evidence. That she conveyed her personal view that Myrick was lying on the stand may have caused the jury to give more weight to her "word" than Myrick's "word."

In the end, it was an abuse of discretion for the trial judge to deny Walker's request for a mistrial on this ground.

$373 \mathrm{Md}$. at 403-04.

In support of its decision, the Court of Appeals relied on (in this author's opinion, inapposite) cases that preclude prosecutors from explicitly personally vouching for a witness's veracity, or from insinuating to the jury in argument that the prosecutor has special personal knowledge (beyond what the evidence has shown) of, or a personal belief in, the defendant's guilt.

The Court of Appeals also relied on three other cases: one of its own, Elmer v. State, 353 Md. 1 (1999); United States v. Edwards, 154 F.3d 915 (9th Cir. 1998); and Berger v. United States, 295 U.S. 78 (1935). Yet none of these cases went nearly so far as does Walker.

Unlike in Walker, the appellate courts held that the prosecutors in Elmer and Berger had deliberately mischaracterized the facts. There was no allegation of misrepresentation in Walker.

Unlike Walker, Edwards presented a highly unusual and awkward situation: the prosecutor had personally discovered a key piece of real evidence, in the bottom of an already 
introduced exhibit, in the middle of the trial. The prosecutor in Edwards had witnesses to his discovery testify to it. In finding reversible error, the Ninth Circuit employed broad language, coupling the "advocate witness" rule with the rule against "prosecutorial vouching."

\section{A. Elmer v. State}

In Elmer, the prosecutor was surprised when one co-defendant, Brown, testified that he, not Elmer, was the shooter. From information provided to the court at the bench, it developed that Brown's attorney had told the prosecutor, during failed plea bargain negotiations, that he expected that his client would testify against Elmer and say that Elmer was the shooter, and that he, Brown, had had no idea that Elmer was going to shoot.

For that reason, the prosecutor asked Brown if he had ever made that statement. Brown denied that he had. When the ASA declined to take "no" for an answer, and repeated the question, Brown's attorney (later joined by Elmer's attorney) objected. At the bench, Brown's attorney acknowledged that he, the attorney, had made this statement, but (seemingly admitting to several ethical violations) said to the judge that he had "never asked my client what he did or not ... until ten minutes before yesterday. ..." $353 \mathrm{Md}$. at 7. See Appendix B, pp. 26-28 of this packet.

The judge overruled the defense objection. After two more questions, and denials from Brown, Elmer's and Brown's attorneys both objected to a third question, and the objection was sustained on the ground "asked and answered." $353 \mathrm{Md}$. at 7-8. The Court of Appeals found unanimously that the ASA's questions were inadmissible as to Brown due to Md. Rule 5-410, but not as to Elmer, because he was not a participant in the plea discussions.

The majority of the Court of Appeals, over the well-reasoned dissent on this point by Judge Chasanow, joined by Judge Rodowsky, went on to hold that the court had committed reversible error (even though no motion for mistrial had been made), because the prosecutor had engaged in "'misconduct in repeatedly pursuing the line of inquiry" when "it was actually known by him to be false"" that "'Brown himself," $353 \mathrm{Md}$. at 12-13, had made the statement implicitly attributed to him by his lawyer. The ASA was vituperated, because " "attempting to give the jury a knowingly false impression presses the limits of judicial tolerance." $353 \mathrm{Md}$. at 13.

Though this was the majority's opinion in Elmer, it misses the mark. Quite arguably, the ASA did not know he was misrepresenting a fact.

At trial, Brown apparently threw himself on the railroad tracks for his buddy and testified, in effect, that he alone was guilty. Brown's prior statement, on the other hand, was exculpatory of him and inculpatory of Elmer. The State sought to impeach Brown, to have the jury disregard the part of Brown's testimony that was exculpatory of Elmer. The prior statement (which, the Court of Special Appeals suggested, resonated with Bruton-type problems), $119 \mathrm{Md}$. App. at 
218-19, was inadmissible as substantive evidence against Elmer. Brown denied making the statement.

But Elmer had sought neither a limiting instruction, nor any instruction to disregard any implications from any lawyer's questions.

\section{B. How Broad is Walker's Brush?}

Walker, building out from Elmer, seized upon the Ninth Circuit's broad language in $E d w a r d s$, regarding the "advocate witness" rule and the rule against prosecutorial vouching. But the Walker facts, unlike those in Edwards, are not unusual; they are of the everyday variety. There was no dispute in Walker that the statements had been made -- indeed, they were made in the witness's attorney's presence, and the prosecutor was willing to call that attorney to the stand, had the judge permitted it.

Walker's language seems to tie the hands of every prosecutor from impeaching any witness with prior inconsistent statements which the question implies were made to or in the presence of the prosecutor. Other lawyers' hands are not similarly tied, however: the Walker court speaks repeatedly of a prosecutor's "unique role" resulting in "special duties," and requiring "higher standards."

In Walker, the ASA attempted to impeach her witness with a prior inconsistent statement he had made to the police. When the witness denied having ever seen the statement, she asked him whether she had shown it to him in her office, a few days before trial. He then acknowledged that he remembered that. Query: if he had denied it, would the ASA's proper question have made her guilty of some misconduct? The language of Walker suggests that it would (and maybe that it did, even when the witness assented?!):

When the prosecutor makes assertions of personal knowledge in the form of questions during either direct or cross-examination the prejudice to the criminal defendant may be significant because the defendant is denied his confrontation rights and is unable to cross-examine the prosecutor to test the veracity of the assertions.

373 Md. at 397.

The Court of Appeals concluded that a mistrial was required when, later, the witness denied having told the ASA that he was afraid to testify, because he (or, more properly, his elderly parents) had been threatened. In apparent disbelief, she had asked him the same question several more times. The Court of Appeals found that, "[b]y [impliedly] asserting that she knew [the witness] was lying, the prosecutor engaged in a form of reverse prosecutorial vouching." If Walker is taken literally, prosecutors cannot even ask uncooperative witnesses about prior statements made in the prosecutors' presence. 
The unfair damage, if any, to Walker stemmed from the same source as in Elmer: a coconspirator had told the police that Walker, not he, was the "bigger fish." The defense attorney did not raise that issue or seek a limiting instruction. He did refer, however, to the risk that the witness had been threatened by or on behalf of Walker. The potential damage there was from the standpoint of "other bad acts" of the defendant, implicitly offered as proof of his "guilty knowledge," without adequate proof of the defendant's connection to the threats, than it was that the prosecutor had asked leading questions based on the witness's prior statements to her. A motion for mistrial on this "bad acts" ground was denied, the trial judge pointing out the witness had testified that he had not been threatened.

The trial judge then agreed to allow one more question along those lines, to show how the prosecutor had been surprised. When that one question became seven, a mistrial would not have been out of order -- if Walker's defense counsel had consistently objected, and his objections overruled; if he had made (and been denied) a request for a limiting instruction; and if he had renewed his motion for a mistrial.

But a mistrial does not seem to this author to have been necessary. After all, the jury acquitted Walker of the drug deal on the date as to which this witness testified, which shows that the jury did not credit the opposite of the witness's testimony.

The Walker result should be restricted to situations where prosecuting attorneys either misrepresent facts or parade inadmissible facts before the jury. Unfortunately, it is not clear that the Court of Appeals will so restrict it. Perhaps prosecutors now must go to the length of saying simply "Did you ever make the statement ...?" or "Did you ever make the statement in the presence of [a named third party] ...?" and not mention that the statement was made to the prosecutor. Is that workable?

If the witness denies having made the statement and its subject matter may be proved by extrinsic evidence, the prosecution could call the third party to the stand (or withdraw from the case if anticipating having to testify herself).

\section{Contradictory Extrinsic Evidence}

When witnesses with first-hand knowledge of material facts give evidence that conflicts with each other's, each gives substantive evidence that also impeaches the other's. For example, one witness may testify that A had the gun, and another witness that B had the gun. Such evidence is, of course, routinely admitted as to material, noncollateral matters, but generally excluded as to collateral matters. Smith v. State, 273 Md. 152 (1974).

Rule 5-616(b)(2), however, permits the court, in its discretion, to admit contradictory extrinsic evidence on collateral matters. McCormick has said that the court may allow such evidence if, "as a matter of human experience, the witness would not be 
mistaken on the [collateral] point if the [non-collateral] thrust of the witness's testimony were true."

Problems. a. State v. D for murder, by arsenic poisoning: "I Smell a Rat"

D's witness testifies that arsenic is kept in the cellar of Victim's and D's house to kill rats who might come in, because food is stored in the cellar. The prosecution wants to call a rebuttal witness to testify that food has never been kept in the cellar.

(I) Is the matter collateral or non-collateral?

(ii) Should the court permit the extrinsic evidence?

b. U.S. v. D for crime in Atlanta, Georgia, on July 14 at 7:00 p.m.

(I) D's witness, W, a large Cockeysville, MD, restaurant owner, has testified that $\mathrm{D}$ is a regular customer, and he thinks he saw $\mathrm{D}$ in his restaurant every night for several weeks prior to July 14 , and for the entire evening of July 14.

In its case in rebuttal, the U.S. calls Police Officer to testify that she saw D in Atlanta, Georgia, on the evening of July 1 and that $\mathrm{D}$ said he had been there for a couple of days.
(A) Collateral or non-collateral?
(B) Admissible? Arguments each way?

(ii) In its case in rebuttal, the U.S. calls Waiter to testify that he worked in the restaurant nights, from June-August, and he never saw D. Waiter was not working on July 14.
(A) Collateral or non-collateral?
(B) Admissible?

c. U.S. v. D for murder at 8 p.m. on August 6

D's Friend testifies that he and D were at the movies at The Charles Theater, watching "My Big Fat Greek Wedding," from 7-9 p.m. on August 6. 
The U.S. wants to offer the Baltimore Sun for August 6, to show that "My Big Fat Greek Wedding" was not playing at The Charles. "Objection! Hearsay! Extrinsic evidence on a collateral matter!" Ruling?

d. W testifies that she saw both D and Law Student X in the Johns Hopkins Hospital garage minutes before D's alleged carjacking victim, V, was stuffed into the trunk. D wishes to call Classmate, to testify that $\mathrm{X}$ was in Evidence class at the pertinent time.

(I) Collateral or non-collateral?

(ii) Best argument for admissibility?

\section{Impeachment of Experts by Learned Treatises}

Counsel has the choice of using learned treatises merely to impeach an expert witness, by contradiction, Rule 5-616(a)(2) and (b)(2), or as substantive proof, in accordance with the requirements of Rule 5-803(b)(18).

\section{Rehabilitation of Impeached Witness}

\section{A. In General}

If your witness's credibility has been impeached, you can discredit the impeachment and rehabilitate your witness by one of three methods:

1. Having your witness -- generally on redirect examination -- either deny the impeaching facts, or explain them;

2. Proving your witness's prior statements consistent with her trial testimony; and

3. Calling character witness(es) to testify to your witness's good reputation for truthfulness, or to the character witness(es)' good opinion of your witness's character for truthfulness.

\section{B. Denial or Explanation}

The first of these three -- denial or explanation -- may be used with regard to every method of impeachment, except that under Maryland law one cannot deny one's guilt of a crime for which one has a prior conviction (but may give a brief explanation of extenuating circumstances). See Rule 5-616(c)(1). For example, a witness may deny having made a prior 
inconsistent statement, or may explain that she made it because she was afraid, or "didn't want to get involved."

\section{Prior Consistent Statements}

The second method of rehabilitation -- your witness's prior statements consistent with his or her testimony at trial -- may be used when the making of the out-of-court statement at the time it was made rebuts the impeachment undertaken (bias, etc.; prior inconsistent statement; or faded memory. See Rule 5-616(c)(2).). More flexibility is permitted for this use than for substantive use under Rule 5-802.1(b). See Holmes v. State, 350 Md. 412 (1998).

A little-recognized statute, Md. Cts. \& Jud. Proc. Code Ann. § 9-117, provides that $a$ party's prior consistent statements may be proved only if they were made in the presence of the opposing party. See Rule 5-616(c)(2).

\section{Favorable Character Witnesses as to Truthfulness}

The third method of rehabilitation of a witness's credibility -- favorable character witnesses as to the witness's character for truthfulness, see Rules 5-608(a) and 5-616(c)(3) -may be employed only when the impeachment constituted an attack on the witness's character for truthfulness. The trial judge will make that latter call, under Rule 5-104(a). (Definitely impeachment under Rules 5-608(a), 5-608(b), and 5-609 would qualify; maybe prior inconsistent statement under Rule 5-613, depending on whether the trial judge sees it as an attack on truthfulness rather than memory. Impeachment by bias, for example, is unlikely to be seen as an attack on the witness's general character for truthfulness, however, and is thus unlikely to open the door to rehabilitation by character witnesses.)

Under a unique quirk of Maryland's case law, a special exception applies to a criminal defendant who is charged with a crime of the type addressed in Rule 5-609 (an "infamous" crime or another crime "relevant to credibility"). If such an accused has testified at trial -- or made a binding promise to testify, Sippio v. State, $350 \mathrm{Md}$. 633 (1998), he or she may offer favorable reputation or opinion character evidence to his or her truthfulness, even if no direct attack on the accused's character for truthfulness has taken place. Sahin v. State, 337 Md. 304 (1995). 


\section{APPENDIX A: Excerpt from Walker, 373 Md. at 367-73}

Myrick was compelled to testify at Petitioner's trial in the Circuit Court for Montgomery County after being promised immunity from state and federal prosecution for his part in the events. Prior to the trial and pursuant to a plea agreement, Myrick gave an oral statement to the police implicating Petitioner. At the start of Walker's trial, however, the prosecutor proffered that she had learned that Myrick was no longer willing to testify and so she moved to compel Myrick's testimony. The court delayed ruling on the motion until after the jury was selected. Outside the presence of the jury, the prosecutor called Myrick to the stand at which time he exercised his Fifth Amendment rights and indicated that he would refuse to testify. After both state and federal immunity from prosecution were secured for Myrick, the court granted the State's motion to compel and Myrick took the stand to testify before the jury.

Myrick gave the following testimony, in pertinent part:

[PROSECUTOR]: [D]id you meet with [Officer Carafano] for the purpose of distributing to him cocaine?

[MYRICK]: Yes.

Q: Did you make arrangements for him to meet you at [the restaurant] for that same transaction?

A: Yes.

Q: And, when you met with Officer Carafano, did he provide you with money?

A: Yes, he did.

Q: And did you go back into the [pizza] store?

A: I believe I did, or I walked around the store.

Q: And where were you going?

A: To go pick up the stuff that I had on the ground.

Q: Where did you pick that stuff up?

A: It was right behind [the restaurant].

Q: And was there anybody behind [the restaurant] when you went back there?

A: Yes.

Q: Who was behind there?

A: Earl Walker.

Q: And did he provide you with that cocaine?

A: No.

Q: What was he doing back there, do you know?

A: I had owed him some money. I had told him when I get off work, I would pay him.

Q: And did you pay him the money that you had owed him?

A: Yes, ma'am.

Q: After you came back from [the restaurant], did you give the cocaine to Officer Carafano?

A: Yes, I did.

The prosecutor then announced her intention to impeach Myrick with his prior statement to the police implicating Petitioner. The statement, although reduced to a writing, was not signed or otherwise adopted previously by Myrick. The prosecutor acknowledged that "[w]e cannot get this statement in as substantive evidence under the Nance case [Nance v. State, 331 Md. 549, 629 A.2d 633 (1993) (holding admissible as substantive evidence the factual portions 
of prior inconsistent statements reduced to writing and signed by a "turncoat witness" who later repudiated those statements at trial)] and the new rules that came along from Nance which do require that any prior inconsistent statement be signed by the individual prior to it being admitted into evidence as substantive evidence." When the court asked the prosecutor whether she was "taken by surprise by [Myrick's] testimony," she replied "[t]his is the first I have heard this particular version." The court also heard from defense counsel who was skeptical about the prosecutor's alleged "surprise." He stated "I think in all fairness, the State [k]new there was going to be problems with Myrick--so, to now claim surprise, I just think is a little poor."

The court found that the State was surprised by Myrick's in-court testimony and permitted the State to attempt to impeach him. The prosecutor continued her examination of Myrick:

[PROSECUTOR]: Mr. Myrick, do you remember giving a statement to the police ... on the night of your arrest on May 4th of this year?

[MYRICK]: Yeah, partially; yes, ma'am.

Q: And do you remember in that statement indicating "I got [a] \$100 rock of crack cocaine from Earl or Eric, drives a silverish colored Honda." I have the statement if you want to see it?

A: Okay. I remember telling him from him bugging me, I remember of some sort. It is not really clear to me, because I was pretty much beat up at the time.

Q: But--

A: So I don't know exactly what I was--you know, I haven't even really seen the statement myself. So I don't know.

Q: Well, that is not true. I showed you the statement on Friday, did I not? ...

[DEFENSE COUNSEL]: Objection to the form of the question.

[MYRICK]: I don't know.

[COURT]: Sustained.

[PROSECUTOR]: Mr. Myrick, were you not shown this--

A: Oh, yes.

Q: --statement on Friday?

A: This one here, yes, I was.

Q: And did you not tell the police "I got $\$ 100$ rock of crack cocaine from Earl or Eric, drives a silverish colored Honda?"

A: Yeah, I did say this on this thing.

The prosecutor continued her questioning of Myrick:

[PROSECUTOR]: Mr. Myrick, you and I met on Friday; is that correct? [MYRICK]: Yes, ma'am.

Q: And at that time I gave you a copy of your statement, did I not?

A: Yes, ma'am.

Q: And did I not ask you at that time whether this statement was the truth?

A: Yes, ma'am.

[DEFENSE COUNSEL]: Objection. Can I approach the bench?

[Whereupon bench conference followed]

[DEFENSE COUNSEL]: Your Honor, based on the question [the prosecutor] just asked, what she did and what her contact with Mr. Myrick is, I am going to ask the Court for a 
mistrial because it puts her as a witness in this case and I don't think she can continue on. It violates all right to confront evidence in this case as to what she said to him and what she did. So, I am going to move for a mistrial.

[THE COURT]: I don't think this is the test. I think the test is she simply stuck with his answers. That is all. I don't think it makes her a witness in the case. I will overrule your objection and deny your motion to mistrial.

[Whereupon the bench conference was concluded]

[PROSECUTOR]: Mr. Myrick, do you remember the question?

[MYRICK]: I don't remember.

Q: [Y]ou reviewed the statement on Friday; is that correct?

[MYRICK]: Yeah, approximately, yeah.

Q: And at that time did I not ask you whether this was a true statement?

A: Yes, you did ask me that one.

Q: And at that time did you say anything to me--

A: No, I didn't say anything to you about it.

Q: Mr. Myrick, you did not want to testify today; is that correct?

A: No, I didn't want to testify today.

Q: And, in fact, you are here by subpoena; is that correct?

A: Yes, ma'am.

Q: And, in fact, you have been ordered to testify; is that correct?

A: Yes, ma'am.

Q: And you are afraid; is that correct?

[DEFENSE COUNSEL]: Objection.

[COURT]: Sustained. Leading.

[PROSECUTOR]: Have you been threatened in any way--

A: No.

Q: Did you tell me on Friday that you had been?

[DEFENSE COUNSEL]: Objection. Your Honor, can I approach the bench now, please?

[COURT]: All right.

[Whereupon bench conference followed]

[DEFENSE COUNSEL]: Your Honor, I move for mistrial, again. The suggestion now

from that question is that my client--even if he was threatened, whatever his answer is--that my client was involved in something like that. That is unfair--

[COURT]: He has already said he wasn't threatened. I will sustain the objection. I will deny the motion.

[DEFENSE COUNSEL]: Your Honor, I would ask the Court to disallow the State pursuing this avenue of question in where it is suggested that my client is involved in any way in his statements to [prosecutor], to his statements to the officers that night. He gave his reasons--

[COURT]: He has already said--you are stuck with his answer--he said he wasn't threatened. So I am not going to let you pursue that unless you have some particular evidence that you--

[PROSECUTOR]: Your Honor, when I met with him on Friday, in [Myrick's attorney] Mr. Schmidt's presence, Mr. Myrick said that his father--his elderly parents--had been threatened, and I am not suggesting--I mean, I don't know whether it is Mr. Walker-I am not sure if it is really important who has threatened him, but that is why he told me on Friday that he no longer wanted to cooperate, and he did not want to testify. 
And I think, given the fact that I now have a witness who is totally changing their story, and I believe, not being truthful, $I$ think I can bring out the fact that he is making all this up now.

[COURT]: Well, that is true. You can do that, but you have already asked him if he was threatened and he said he wasn't.

[PROSECUTOR]: But why can I not ask him when I met with him on Friday in the presence of Mr. Schmidt, whether he told me at that time he had been threatened or not and that is why he didn't want to testify and he can say yes or no.

[DEFENSE COUNSEL]: This is extrinsic; this is collateral. You know, we come into the situation where surprise is claimed and now you keep getting all the extra stuff with it that has nothing to do with it.

[COURT]: But their testimony bolsters the State's argument for surprise. I will allow that question. I will overrule the objection.

[Whereupon the bench conference was concluded]

Q: Mr. Myrick, when I met with you on Friday, didn't you tell me that you had been threatened?

A: No, I don't recall. I don't remember.

Q: You don't recall telling me that?

A: No, ...

Q: And did you not tell me that you didn't want to testify?

A: Yes, I did tell you I didn't want to testify because--

$Q$ : Because you were afraid?

A: No, because the statement I wrote was a lie, and I am not going to convict somebody with my wrongdoings.

Q: That is what you told me on Friday.

A: No. That is what--I didn't tell you anything....

Q: Mr. Myrick, on Friday, when we met in the presence of your lawyer ... you knew I was a State's Attorney, did you not?

A: Right. Yeah. I just wanted to hear what you were trying to say to me.

Q: And did you not tell me that day that you had been threatened and that is why you didn't want to testify?

[DEFENSE ATTORNEY]: Objection.

[THE COURT]: Sustained. 


\section{APPENDIX B: Excerpt from Elmer, 353 Md. at 4-9}

In a joint trial, Brown and Elmer proceeded to trial before a jury. A significant issue developed at trial as to which person in the car actually fired the shotgun--Brown or Elmer. Elmer did not testify. Several witnesses testified that they saw the shotgun through the passenger's side and that Elmer fired the shot that struck Mr. Earl. Brown testified that he reached over and pulled the trigger as one of the bystanders was aiming a large chunk of granite at the car window and that Elmer was trying to avoid being hit with it. Brown's testimony that he pulled the trigger, and not Elmer, led the prosecutor to inquire of Brown on cross-examination:

THE STATE: Mr. Brown, did you ever make the statement that when you came down around the curve ... your attention was drawn to the people that were running from your left, and that at that point in time Allen Elmer put that gun out the window, pulled the trigger, the gun boomed, and the first thing you said to him is what the F did you do? Did you ever make that statement?

[COUNSEL FOR BROWN]: Objection. May we approach the bench?

THE STATE: Did you ever make that statement, Mr. Brown?

[COUNSEL FOR BROWN]: Your Honor--

THE COURT: It's cross-examination.

THE STATE: Did you ever make that statement?

[COUNSEL FOR BROWN]: Your Honor--

THE COURT: Just a minute. Come on up.

The following discussion took place at the bench.

THE COURT: What is your objection?

[COUNSEL FOR BROWN]: I am trying to make sure that [the prosecutor] is not trying to get into attorney/client privilege. The attorney who he was making the statement to--clarify that, please.

THE COURT: Well, if he made it to you, how would he know about it? If he made it to you, how would [the prosecutor] know about it?

[COUNSEL FOR ELMER]: I object. Objection.

[COUNSEL FOR BROWN]: My objection is I want him to clarify who he made the statement to.

THE STATE: All I have to ask him is if he ever made that statement.

THE COURT: You're overruled.

The bench conference concluded and the prosecutor continued before the jury:

THE STATE: Mr. Brown, I think you heard the question, but I will ask you again. Did you ever make the statement, Mr. Brown, that--when you came down around this curve that your attention was drawn to the people who were coming from your left, and you're looking out there, out the driver's side toward those people on the left as you heard--don't look at [counsel for Brown].

[COUNSEL FOR BROWN]: I am making the objections. He is looking at me.

THE COURT: I am overruling you. You are looking at the attorney.

[COUNSEL FOR BROWN]: Your Honor, we need to approach the bench again. 
THE COURT: No, no, you are not approaching the bench. He is asking questions. I've already ruled on this. Go ahead.

[COUNSEL FOR BROWN]: Your Honor, it's on a separate matter. I need to approach the bench for the record, please.

THE COURT: Come on up.

The following discussion took place at the bench.

[COUNSEL FOR BROWN]: Your Honor, [the prosecutor] asked in settlement negotiations what would my client testify to, and during settlement negotiations I told him what my client would testify to. I never told him my client said that. That was part of the settlement negotiations for--

[COUNSEL FOR ELMER]: In all fairness, good conscience, fairness, he can't use something like that now when negotiations--

THE COURT: Is that what you are using now?

THE STATE: Yes, I am. Let me tell you how this went though. This is-- [counsel for Brown] came to me, and said his client was willing to plead guilty to reckless endangerment, and his client wanted to testify in my prosecution of this defendant; and his client would testify just exactly the same that I am asking right now.

[COUNSEL FOR BROWN]: No. When I said--he asked, what do you expect your client to say. I said, I would expect my client to testify--

THE STATE: And he continually said that's what the witness had said.

[COUNSEL FOR BROWN]: I never intentionally asked my client what he did or not what he did until ten minutes before yesterday.

THE COURT: What you--

[COUNSEL FOR BROWN]: He asked what I expect him to testify to. I never-THE COURT: You are overruled. You have your objection.

[COUNSEL FOR BROWN]: Thank you.

Before the jury, the prosecutor again inquired:

THE STATE: Mr. Brown, you made the statement, didn't you, that when you came around this curve on Willow Drive that your attention was drawn to the people over on your left hand side, and that you were driving, and you are watching them when you heard the boom of a shotgun; and you looked over at Mr. Elmer and said, what the F did you do that for; and Mr. Elmer said to you, I shot the car. Didn't you make that statement?

BROWN: No, I did not make that statement. That was how it was stated in newspapers and stuff; and at that time no one had given me a chance to tell my side of the story, what happened down there that day. I was never given a chance to explain what happened or anything like that. And in my charging documents that was what had been said. So that is what $I$ had went along with to try to get those charges filed against the attackers who admitted to attacking, which you have let go; and that's so they can get away with attacking people. That's--I mean, I know it is a terrible shame that somebody got hurt in this incident. That could have easily been me and Allen on that stretcher flying to Shock Trauma. Does that give them the right to attack us?

THE STATE: Mr. Brown, didn't you say that you would testify to just that in the prosecution of Mr. Elmer? 
BROWN: No, I did not. That was never said, no. I never said I was going to testify. I am saying that now here. I am right now sitting here finally--finally after a year and six months in jail, free of all this terror and nervousness and pain and everything that me and my family has had to suffer. I'm here now finally getting to tell the truth, and what really happened in this case.

THE STATE: Did you ever communicate to me that you were going to testify, or you'd be willing to testify in the prosecution of Mr. Elmer?

[COUNSEL FOR ELMER]: Objection.

[COUNSEL FOR BROWN]: Objection.

THE COURT: Sustained. It's already been asked and answered.

Counsel again approached the bench and the following colloquy occurred:

[COUNSEL FOR ELMER]: I want to formally object for the record that Your Honor permitted the state's attorney to ask questions about plea negotiations, or questions after it was plea negotiations, preliminary.

THE COURT: This was already objected to.

[COUNSEL FOR ELMER]: But you permitted him to continue. That's totally wrong for a state's attorney--

THE COURT: You've already got your objection. What are you bringing it up again for?

[COUNSEL FOR ELMER]: Because we--for the record.

THE COURT: You got it for the record the first time. You have it on the record, gentlemen. 